\title{
WILDFIRES AT THE EDGES OF SCIENCE: Horizoning Work amid Runaway Change
}

\author{
ADRIANA PETRYNA \\ University of Pennsylvania \\ (iD) http:/ / orcid.org/0000-0002-8952-7559
}

The year 2015 had been the worst wildfire-fighting year on record in the United States. Wildfires consumed 10 million acres, and the war on wildfire cost taxpayers $\$ 2.6$ billion. In California alone, about 3,400 wildfires were fought, 1,000 more than the average over the previous five years. Fire seasons are lasting, on average, eighty-six days longer than they have in four decades. For two weeks in 2015, recruiters in the national dispatch and coordination system hit a resource limit: there was simply nobody left to recruit to fight the fires. Military personnel, volunteers, and even prisoners were conscripted into emergency response efforts.

The truth is that it is hard to find stability in these numbers. As the future unfolds, these numbers (of acres burned or costs accrued for any given year) become distant benchmarks of runaway change. This became evident in 2017, when new records were set and dispatch services once again hit novel breaking points with exhausted fire crews and widespread pollution and destruction. California, with more than nine thousand fires, saw the first ever wintertime megafires in December of that year, during "what should be the peak of the state's rainy season" (Holthaus 2017). As one observer of these fires noted: "I was expecting to see snow on that mountain, and now the thing is on fire" (Downey 2017). 
Runaway change, understood by climate scientists as a rapid departure from long-established baselines, systemic patterns, or historical trends, becomes more than an accretion of ecological surprise; it renders untenable the very concept of projection. Climate models predict how climate change will continue to have a serious impact on the planet. They are, however, imprecise in forecasting when and where the next megafire, superstorm, or flood will be (NPR 2016). One can think of this opaque quality of runaway change not just in terms of how change escapes received explanations and models, but of how projections degrade, validating the problem of climate change as an unchecked race against time. One can also think of runaway change as signifying a gulf between what is expected and what actually occurs: an empty dimension that might not be so empty after all, but rather an elaborately staged absence, more like a vacuum, in which certain knowledge of the thing itself — wildfire, for example — continually disappears. ${ }^{1}$ If this is the case, namely, that runaway change conceals within itself the impetus for its own progression, then what does it take to render this change observable and, if possible, to slow it down? How are temporal horizons being rendered with respect to runaway change? How can actionable time be recovered or pried away from the pace of its advance? What would it mean to gain ground in this peculiar race against (lost) time, and what is at stake for agency and retreat in the negotiation of surprise?

In the past decade, scientists have engaged in a peculiar exercise of time reckoning with certain aspects of the global climate system. Concepts aiming to ascertain sudden or far-reaching modifications in particular subsets of ecosystem dynamics, such as critical thresholds and regime shifts, have proliferated in ecological science (e.g., Lenton 2011; Dakos et al. 2012; Scheffer et al. 2012; Drijfhout et al. 2015). ${ }^{2}$ Critical thresholds are theorized moments at which characteristic behaviors deviate from known patterns or trends. Regime shifts manifest as breakaway processes, for example, in structures and functions of ecosystems. As they surface, they rupture a so-called climate envelope for particular residents, binding them to another ecological milieu. ${ }^{3}$ Different, unforeseeable constraints on survival or possible extinction arise. The suddenness of the shifts between milieus might also be hard to perceive. Changes can register as anomalous at first ("that fire season was long”) but stabilize into a new state of ecosystem organization ("fire seasons are getting longer"). Their impact can be observed at a regional or more context-specific scale ("that mountain is burning"). But by this time, the realization that the new conditions may not be survivable comes too late. 


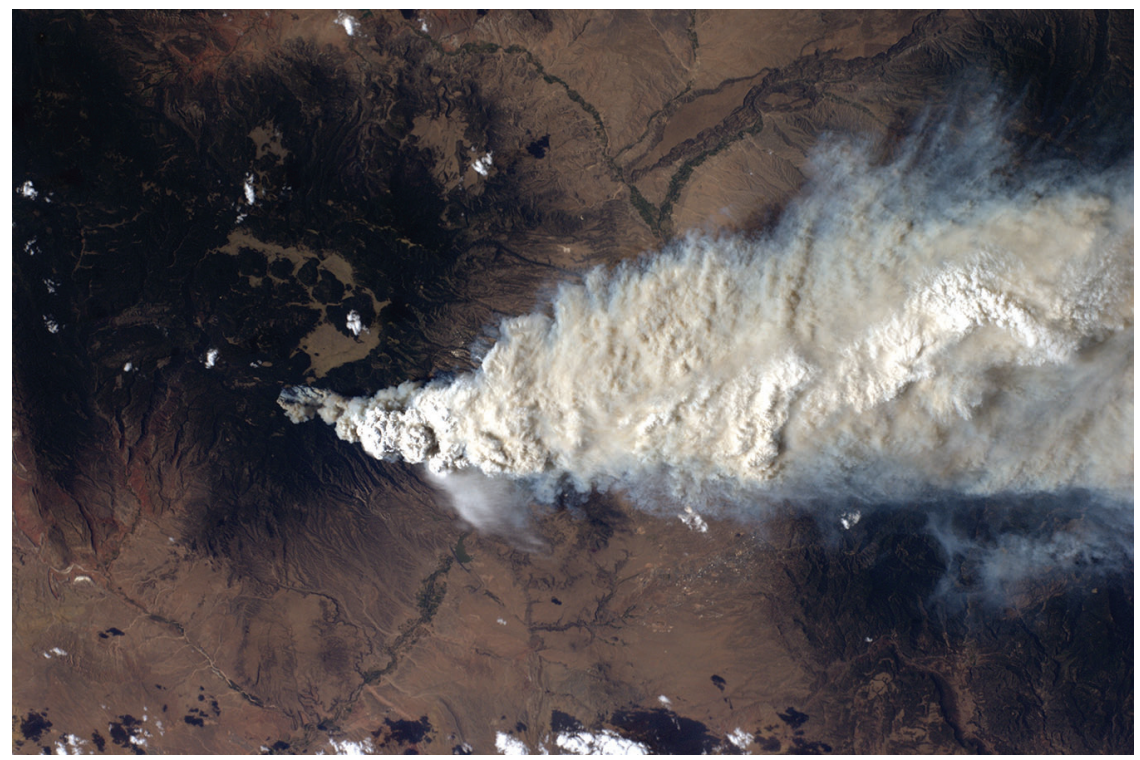

Figure 1. The 2011 Las Conchas Fire in the Santa Fe National Forest, as viewed from the International Space Station. Photo by Los Alamos National Laboratory, licensed under CC BY-NC-ND, https://www.flickr.com/photos/losalamosnatlab/5926991831.

According to the scientific literature, the mutually reinforcing feedback processes that drive regime-shifting events are either only partly quantifiable or entirely unobservable, making anticipatory thinking on structures that could "guide" (B. Lin and Petersen 2013) transitions a difficult enterprise. Projections falter in the face of runaway change. For example, the predicted timing of the West Antarctic Ice Sheet's collapse was misjudged and its magnitude underestimated; projected intervals (so-called return periods) of coastal flooding events have also proven to be ineffectual (or arbitrary). ${ }^{4}$ The extreme event becomes the product of a projection that actively denies concerned publics a foothold in changing climate milieus, such that, according to the geoscientist James White (2014), scientists are left with "areas of observation where we are largely blind . . . . As a scientist, my hope is that we can study the planet well enough, monitor it well enough, understand it well enough, that we're not going to be blindsided. As a realist, I'm pretty sure we're going to be blindsided." White suggests that being repeatedly blindsided is an ineluctable consequence of a rapidly changing physical world. As one engineer working with coastal scientists to improve infrastructures on the U.S. North Atlantic coast suggested in a lecture: "There is a switch beyond which we cannot plan [for resilience]" (Nordenson 2016). Yet if extreme events 
reflect dynamics that deny us a foothold, then at each step in the disintegration of our projections, there is new work to do.

This essay explores such work in the specific context of wildfire and asks: how do faltering scientific projections interface with the realities of emergency response? In pursuing points of contact and broadening disconnects, my ethnographic inquiry has taken me into two disparate but related fields. The first concerns theorists who are not focused on wildfire specifically but are, on a planetary scale, attempting to define varieties of critical thresholds that, if crossed, may entail irreversible ecological change, and who are characterizing early warning signals for such changes (Petryna 2015). The second (and the focus of this essay) concerns ground-level actors who are directly caught up in such change and are tasked with trying to contain wildfire proliferation in the United States. In this second field, fire behavior analysts are going back to basics in wildfire science to understand a phenomenon they thought they already knew. ${ }^{5}$ My research among these scientists, training and technical specialists, and engineers has led me to explore at length how fire's new qualities and dynamics can eclipse human and technical competencies. What is a meaningful baseline against which to calibrate progression or retrogression in the fight against fire?

Where unknowable futures meet the demands of emergency response, I track what I call horizoning work: local and highly practical forms of research that attempt to bring an unknown or runaway future into the present as an object of knowledge and intervention. This exercise of the imagination entails not only confronting present or near-future shifts and seemingly inevitable points of no return, but also grasping horizons and bringing them to bear on present operations, where knowledge can be made actionable and not obsolete. This is a race to secure (actionable) time, which calls for a fine-tuned awareness of jeopardy amid incomplete knowledge, and for labors of continuous recalibration amid physical worlds on edge.

In what follows, I draw the reader into this horizoning work, including the daily labors of perceiving critical thresholds, determining baselines, and carving out footholds in stressed and flammable ecological conditions. How do assumptions underpinning one predictive enterprise fall apart and yield another? What are the implications for agency in negotiating the specters of inevitability and surprise? How to apprehend, fight against, or forestall a process in which, as one scientist told me (referring to forest loss), “you're going to see something go away"? 


\section{WHEN PATHS DISAPPEAR}

Before turning to this work, however, let me step back and consider other, perhaps more familiar framings of these present and future-oriented challenges. The image below, adapted from the fifth assessment of the Intergovernmental Panel on Climate Change (IPCC), indicates four possible greenhouse gas-concentration trajectories plotted out to the year 2150. These trajectories contain information about concentrations of atmospheric $\mathrm{CO}_{2}$, their rate of change, and the impact of four mitigation strategies that shift the planet toward or away from stabilization. The lowest path represents a stabilized scenario, in which $\mathrm{CO}_{2}$ concentrations hover around 450 parts per million (ppm). In the words of the sociologist of climate change Kari Norgaard $(2011,9)$, this is "where we need to be in order to be comfortable." Today, most observers would agree that prospects for such stabilization have diminished. In a worst-case scenario, indicated by the highest path (and which many now believe is the most realistic scenario), levels of $\mathrm{CO}_{2}$ will reach $1450 \mathrm{ppm}$, at which point, in the words of the environmental scientist Stephen Pacala, "the monsters will come out" (Guterl 2012, 4) —monsters like firestorms and large-scale global extinctions.

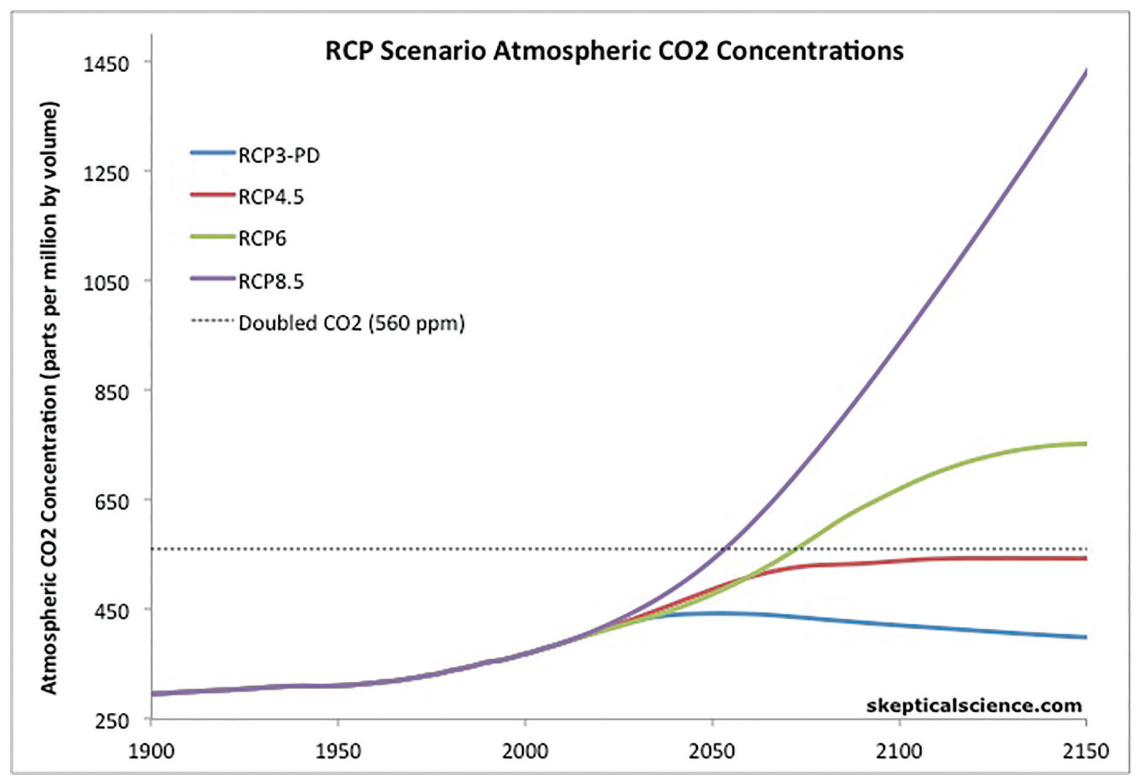

Figure 2. Representative concentration pathways of future $\mathrm{CO}_{2}$ concentrations (blue or lowest curve: best-case scenario; purple or highest curve: worst-case scenario).

Image drawn by Dana Nuccitelli, licensed under CC BY, http://skepticalscience.com/climate-best-to-worst-case-scenarios.html. 
Each path, in the end, is a statistically distilled mass of observations and a dim "analogue of physical reality" (Mahony and Hulme 2012, 78; see also Randalls 2015). Each starts and ends at an arguably arbitrary year; within selected windows of time, paths shift. The world's fate is understood to head toward different possible futures, through more or less likely risk scenarios - transported down paths that destine but also, to borrow from Tim Ingold (2011, 44), "merely skim the surface of the world." To be sure, what burned the mountain in California that should have been covered in snow-nonlinear temperature increases and feedbacks making fuel explosive and wildfires monstrous - forms part of an altogether different reality, one that cannot be easily mapped. Here, the mutability of runaway change does not permit a predictive horizon. What becomes of wildfire next is anyone's guess.

I am interested in this latter path: the one in which wildfire intensifies and defies representation, posing complex operational challenges and appealing for novel engagements with the very concept of projection. ${ }^{6}$ That path plots breakouts and surges (such as wildfires breaching the norms of their frequency, size, intensity, seasonality, or spread), rather than incremental sequences that lead to an arbitrary shift or end. That path moves toward irreversibility, rather than assuming (erroneously) that "a choice can always be made to quickly reduce emissions and thereby reverse any harm within a few years or decades" (Solomon et al. 2009, 1708). That is the path on which the very concept of containment is confronted by wildfires that grow out of proportion with — and can become largely independent of - expected trajectories.

A recent study found that what is known as "global burnable area" (Jolly et al. 2015, 1) has doubled over the past three decades. Affected by longer fire weather seasons, wildfires, as Matt Jolly — the lead author of this study - told me, are transitioning "from one fire type to another much faster type; that is definitely something that is happening more often."7 These spatiotemporal trends point to what he calls "the upper limits of bad." At these upper limits, wildfire's rogue nature erases comfortable distinctions between dead fuels (that burn) and live fuels (whose burning differs from dead woody fuels and is less understood). It also erases distinctions between rural wildland fires and urban conflagrations. In the words of the noted wildfire research scientist (and Jolly's onetime colleague) Jack Cohen, such geographic distinctions are "not relevant to the physics of what is actually happening" (Curwen 2017). Or, as the wildfire historian Stephen Pyne observed after the 2017 firestorm in Santa Rosa, California, the fires "seem to be going where the houses are" (Curwen 2017). 


\section{“IT WASN'T SUPPOSED TO BURN THAT WAY”}

The new conditions of wildfires are obliging firefighting organizations to revise knowledge calibrated to a world that no longer exists. Indeed, the "upper limits of bad" index a lost expertise and the search for a new one. "We should be treating these wildfires the same way we do hurricanes," Bill Armstrong told me. "Get the hell out of the goddamn way." Armstrong is a forester and fuels specialist with the Santa Fe National Forest, and meeting him in 2015 put me on a path of inquiry that brought me to wildfire scientists like Cohen and Jolly at the Fire Sciences Laboratory in Missoula, Montana. They and others I would encounter on this path showed me what they called the "relevant physics" of what is happening and how, through research, they are attempting to gain an empirical foothold in new fire dynamics while avoiding being cut off from knowing thema cultivation of what Donna Haraway $(2016,35)$ calls "response-ability," which precludes a "surrender [of] the capacity to think." Haraway $(2016,35)$ cautions against any such surrenders in a time of "onrushing disasters, whose unpredictable specificities are foolishly taken as unknowability itself.” These fire scientists agree.

In addition to his years of forestry work, Armstrong is a veteran of wildland firefighting. He is an advocate of prescribed burns and a critic of the U.S. Forest Service's century-long policy of fire suppression. But, in a local forest supervisor's office in Santa Fe, New Mexico in 2015, he described unexpected paths in a decade that saw an "exponential rise in area burned." One particular fire stood out: the 1996 Dome Fire in northern New Mexico, whose physics were unlike anything he had ever encountered. According to Armstrong: "In the eighties, when I started, intense fires were anomalies. What we thought was a freak incident became a wakeup call that nobody woke up to. It was a plume-dominated firemore like a firestorm, with so much energy released in such a small period of time. We just weren't expecting that kind of fire behavior." A plume-dominated fire is characterized by huge updrafts of burning embers that pull material high into the clouds: "As material moves up through the clouds, it cools off, and when it cools off, the weight of the cloud can no longer sustain itself. Then the clouds collapse, and when they collapse, they throw shit everywhere." The plume's behavior echoes Timothy Choy and Jerry Zee's $(2015,211)$ concept of the atmospheric, of "how things lift and settle in mediums." In fact, this manic cycle of suspension and collapse can play out repeatedly. Plume-dominated fires have become more common over the past few decades as drier fuels make for higherintensity fires and thus greater interactive coupling between these fires and atmospheric conditions. 
By the mid-2000s, what had previously been an anomaly (Armstrong's "freak incident”) became the norm. Armstrong was a first responder for the 2011 Las Conchas fire, which, like the Dome Fire, defied behavioral models and assessments. Fires usually move with winds, but Armstrong noted that the plumedominated fire at Los Conchas "burned with greatest intensities and greatest rates of spread against the wind. It actually managed to push its way up against the wind." This meant that the fire, "with its own internal winds and its own weather system . . . was feeding itself." ${ }^{\prime 8}$ Furthermore, unlike previous fires, the Los Conchas fire eerily and aggressively "burned into areas where we thought there was absolutely nothing left to burn. It burned through the Cerro Grande wildfire scar of 2000. It burned through the old Dome Fire scar of 1996. We could not have predicted that kind of fire behavior."

\section{FIRE HURRICANES}

The concept of runaway change denotes the changing nature of wildfire formations, whose erratic behaviors can foil emergency responders' efforts to understand them and respond. Not only do these fire behaviors hasten permanent forest loss (Walker et al. 2018), they are opening a gap between what is expected and what is encountered that, in Armstrong's mind, is growing too wide to bridge. For him, discrepancies between what fire behavior analysts predict and what emergency workers face reflect a new pathological normal. ${ }^{9}$ People, including firefighters, need to "get the hell out of the way," just as they do with hurricanes (presuming they can).

I admit that at first I did not know what to do with Armstrong's wildfire/ hurricane comparison, but it kept nagging at me. Both, I came to realize, are hyperobjects that are "massively distributed in time and space relative to humans" (Morton 2013, 1) _ even comparably so in some cases. Both are fueled by "gradients in temperature, pressure, or speed that are responsible for their genesis" (De Landa 2010, 116) and which, theoretically, can never be reversed. In Armstrong's absurdist image of a hypothetical disaster: "We don't get out in front of hurricanes with fans, trying to change their direction. We don't get out in front of tornadoes, trying to turn them around."

Indeed, the two hyperobjects are subject to very different forms of physical management: hurricanes are allowed to run their course, wildfire is suppressed (more or less successfully). Only in 2017, when I spoke with emergency coastal managers just an hour from my hometown in New Jersey, did I start to see other distinctions. Unlike fire management, emergency coastal management is a high- 
tech affair. The decision to evacuate coastal populations is based on a relatively clear and automated signal; as one manager in Monmouth County described, it is a "threshold based on the National Weather Service's forecasting of tidal surge or tides based off the Sandy Hook [New Jersey] gauge . . . So, just throwing a number out, if the gauge reads nine and a half feet above mean low or low water at the Sandy Hook gauge, that triggers my voluntary evacuation of everyone in Monmouth County in Zone A.” In wildfire management, though, there is never an automatic alarm to signal retreat. As one fire scientist told me: "I don't think using the term retreat is very popular with firefighters. Retreat is seen as a retasking." One wildland fire specialist told me about an "alarm-bells-going-off-andyou're-[still]-going sort of mentality." As he phrased it: "We don't have a mechanism to say "no."”

All these hyperobject comparisons would lead me to other awkward facts: as billions of dollars are being poured into wildfire suppression to protect public lands and private property, the efficacy of suppression is "unknowable in an exact sense" (Short 2017, 33) — and yet retreat remains unthinkable. What kinds of logistical orientation to fires-as-hurricanes are occurring under such conditions, and what life-and-death adjustments must be made? In following the path that Armstrong set me on, I met fire researchers who, in some cases, are starting from scratch in their attempt to model wildfire behavior and spread. I encountered wildfire-fighter supervisors who, among other things, are now urging workers to shed their "old mental slides," or once informative guides to fire behavior that are now leading to serious misestimations. This path also included research physiologists who are assessing firefighters' work performance under (now multiple) days of heat exposure and revising physiological standards to guide recruitment. Along the way, I also met research and development engineers redesigning emergency fire shelters - four-pound devices of last resort used by U.S. wildland firefighters when they run the risk of wildfire entrapment.

These women and men are experts not because they are masters of a disembodied discourse, but because they are in privileged positions to apprehend runaway change as it unfolds around them and within a critical subset of ecological dynamics. ${ }^{10}$ As David Rojas $(2016,16)$ has observed in Amazonia, experts slowing deforestation cross the nature-culture divide to "immerse themselves in what they felt were irreversible, uncontrollable, and disruptive socioenvironmental transformations." Similarly, for firefighters, there is no ahistorical sense of fire, but fuel trajectories that are remade or distorted. These do not lead to end-ofnature doomsaying but point toward horizons yet ungrasped, without which, to 
borrow a phrase from Nigel Clark (2012, 260), “'our' agency would be an abstract and orphan presence in the universe." Expertise also indexes nonexpertise, in which biophysical registers of instability and the unappraised aspects of emergency response converge (from the late Latin convergere, "to incline together") to build new capacities. In practice, this means that experts are obliged to find waysscientific, perceptual, even physiological — of recognizing and pushing against the limits of what is known, or else be pushed up against, or blindsided by, those same limits. In quantifying complex hazards, they objectify situations for which older operational models (and "mental slides") have proved inadequate. The epistemic horizon at which experts either acquire a foothold or lose it is unstable; their attempts to intervene in socioenvironmental transformations sometimes reveal conditions of futility, and sometimes they produce new insights that can justifiably keep firefighters working and engaging fire. In what follows I explore this instability, this time from the perspective of someone whose assumptions about predictability have been shattered, in part by the experience of entrapment.

Unlike their counterparts in many other wildfire-prone countries, U.S. wildfire fighters work in immediate proximity to fire. They are trained to remain aware at all times of available escape routes, nearby clearings, and safe spots that have already burned over (called "the black" by firefighters). To minimize the risk of entrapment, particularly when digging out fire barriers (so-called firelines), they are trained to "keep one foot in the black" - that is, to maintain access to a designated safety zone. They deduce the size and location of a safety zone from flame geometries and on the basis of (continually updated) guidelines for how to make these deductions. As changing conditions are more readily felt, these practices of enhanced situated awareness become less reliable. Sometimes, there is no black and, with unburned fuels, drought conditions, and rising temperatures, even the black somehow burns. Crewmen can lose their way in the shifting smoke and flame, particularly as they depend on others (squad leaders, lookouts, superintendents, and so on) to radio them about what is going on or what to expect next. ${ }^{11}$ When information is limited or communication breaks down, they must focus on getting to a safety zone or else, in a worst-case scenario, prepare for imminent entrapment and deploy their fire shelters. A fire behavior analyst referred me to his colleague, Tony Petrilli, a former smokejumper who now works at the Forest Service's Missoula Technology and Development Center. ${ }^{12}$ Petrilli told me that, in this swirl of onrushing disaster, survival sometimes comes down to a coin flip. 
Yet when a fast-moving wildfire swept through Yarnell, Arizona in 2013, killing nineteen highly skilled firefighters who had deployed their fire shelters, Petrilli told me that there was "no flipping of nothing." A postaccident investigation of the Yarnell Hill Fire cited surrounding temperatures of over two thousand degrees Fahrenheit. The fire surprised the firefighters, who were in a box canyon, which blocked their view of the spread and speed of the fire. As Petrilli told me, "fifty-mile-per-hour winds were pushing flames pretty much parallel to the ground [in] a ton of red-flame contact." The deployment site was "not survivable.”

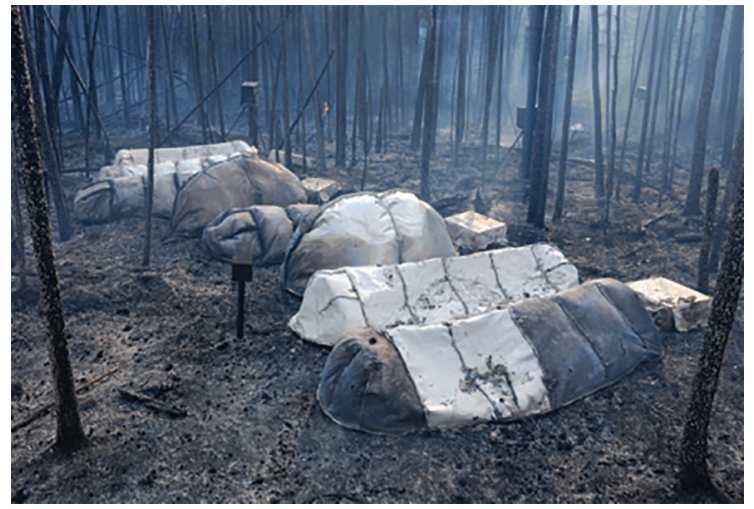

Figure 3. Test of new fire shelters in Canada's Northwest Territories. High temperatures melted the aluminum covering, exposing heat-resistant silica cloth. Photo courtesy of Ian Grob/U.S. Forest Service.

Petrilli personally survived a major blaze (the 1994 South Canyon Fire) by deploying a fire shelter. He "went through the porthole," as he put it, and survived, while fourteen other wildland firefighters did not. My conversations with Petrilli made me appreciate how tough it can be for firefighters to even see the same thing when looking at wildfire at very close range (is it moving faster or slower?), when looking at the ground (has it burned out or will it burn?), or when looking into the distance (and then, Petrilli told me, “it's like, boom, here's the fire"). This perceptual divergence is not unusual, but it can undermine the chance of shared understanding on which coordinated fire management so critically depends: "It's like trying to . . . no offense to cats, but there are a million ways to skin a cat.” A fellow smokejumper who survived the South Canyon Fire described its heat like a wave hitting him. Add strong winds, falling embers, and choking smoke to this chaotic scene, and the idea of deploying shelters that are "flapping crazily" (National Interagency Fire Center 2014) amid roaring fire seems 
challenging at best. Petrilli and his colleagues redesigned these shelters' handles to be quickly deployable, and he has made training firefighters in the use of shelters his life's mission. Yet efforts to prepare trainees do not always translate into effective responses in the field. Since his near-fatal experience, Petrilli has conducted numerous postaccident reviews of fire entrapment cases, where he finds the forensic consequences of the "million ways" of saying "I don't need [to deploy the shelter] yet." 13 What follows is an excerpt from our conversation as he showed me a video used in wildland fire-safety training courses. Some firefighters on the verge of entrapment will still hesitate to deploy their shelters. We were talking about that hesitation as the dread of becoming the subject of a review.

AP: Is [not deploying the shelter] an ego issue then, like, "I'm going to feel humiliated if I use it?"

TP: I wouldn't call it ego. I would call it: "We're OK, we're OK, we're OK.”

AP: OK, meaning?

TP: Meaning, you're in your vehicle on sheer ice and you're spinning around; you're telling yourself, "You're OK, you're OK, you're OK." You're OK until you run into another car or off the road.

AP: In your forensic reviews of entrapment, what does that look like? Do you see evidence of that denial?

TP: I see it more like waiting, waiting, waiting.

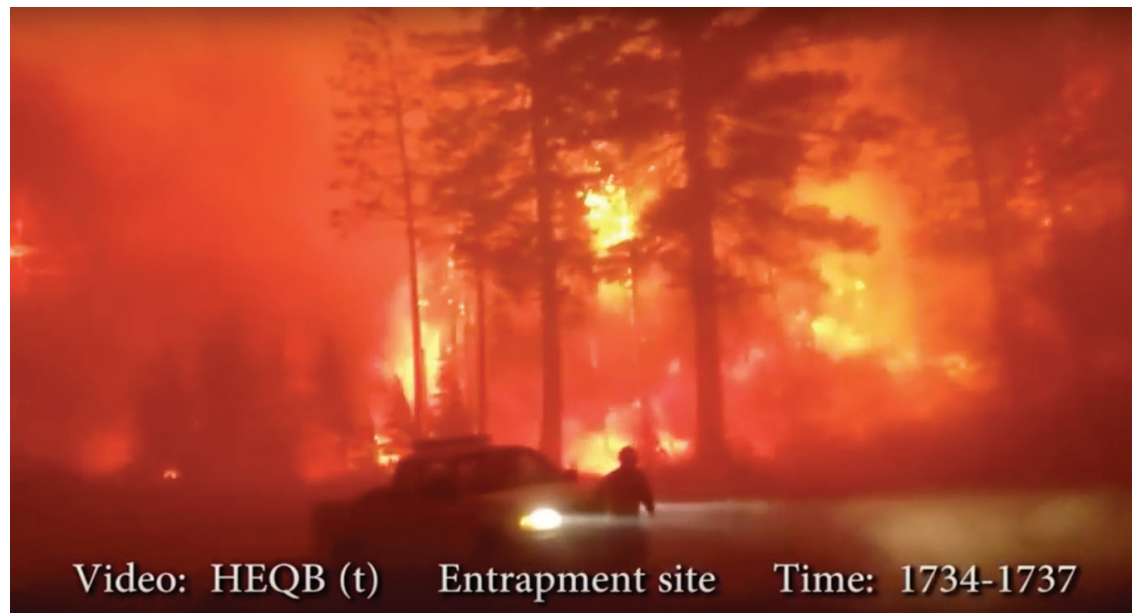

Figure 4. Still from training video produced by the Wildland Fire Lessons Learned Center, https://www.youtube.com/watch?v=MYENvpiv1 WA. 
Petrilli went on to describe the all-too-common practice of "waiting for facts to emerge . . . when we think objectivity is just down the road." The short training film we were watching on his computer screen showed what this waiting could look like. The footage was from the 2014 fire in northern California. Firefighters were "dozing out a safety zone" when the fire switched directions and came their way.

TP: One of the guys had his cell phone video going and it's like, "The fire's coming. The fire's coming. The fire's coming." They're talking about it. They have their fire shelter in their arms. They're talking about it. And it's like_as I'm sitting there watching it—it's like: "OK, how about now? How about now?"

AP: Tell me what's going to happen.

TP: They'll live. But they waited until [now]. So the-this guy's taking photos and the other guy's taking video.

AP: OK.

TP: And so this [safety zone] is freshly dozed. You're starting to get the burning embers.

AP: Yeah.

TP: The fire's going to cross the trail up here. You see, it's starting to come.

AP: Yeah.

TP: And that's a minute later.

AP: Mm-hmm. Whoa!

TP: The fire is starting to suck in all the oxygen.

AP: You can see that, with all the dust you can-wow.

TP: Yeah. I mean, it's coming. I'm ready for them to get in their shelter, right now.

AP: And you're saying, "please get in your shelter."

TP: I mean, you don't want to yell at people, but come on.

AP: But they're filming away.

The time is up, but making self-preservation a common value out of divergent perceptions of reality is hard to do. Who will act on first hints and who will hold out for the last fact is not always clear in advance. In this case, in spite of all the stress training, the firefighters are still working in their safety zone; they might believe they are acting on protocol - in this case, digging out a large safety zone even though it still would not be enough. Regardless of their motives, images 
like these provide powerful lessons; they remind viewers that these firefighters are just like "anybody and everybody," in Petrilli's words, and that "it can be you" who thinks that it isn't going to be all that bad.

TP: You can hear the bulldozer in the background. He's still plowing around-pushing around.

AP: Thinking that's going to work.

TP: Just trying to make [the safety zone] as big as they can.

AP: OK.

TP: The bigger, the better. I don't blame them for that, but now it's time to call it, and he's still going.

As this work continues, it becomes apparent that the firefighters will soon be entrapped. But right before that, they are following protocol, or in denial, or underestimating the speed of the fire, or relying too heavily on mental slides from previous fires - or all of the above. Operationally speaking, Petrilli brings the viewer (me) to a precipice at which certain projections fall (or must fall) apart and make way for new intuitions and responses. The philosopher of science Gaston Bachelard $(1964,6)$ once wrote that fire is a scene of emotive states, of "rigid mental habits," of "phobias" and "philias" that cripple the objectivity of a science of fire. What is the point at which perceptions of fire become too variable? For Jack Cohen, the wildland fire researcher, the fact that it is all of the above (and more) suggests that “we don't have an intellectual perspective on something that is kind of a big deal: fire." But defining increments of improvement and creating actionable time in wildfire management are confounded by other factors as well.

\section{AN AWFUL LOT OF REALITY}

Today, wildland fire researchers with the U.S. Forest Service are going back to the basics of fire, researching mechanisms of wildfire spread and even the properties of ignition. These phenomena seem extremely elementary, stunningly so, especially if one considers that more than half of the Forest Service's budget is now focused on fighting fires. But the longstanding fixation with suppression, especially after World War II, meant that the science of wildfire had limited itself to an image of controllable wildfire. According to the fire behavior scientist Mark Finney, Cold War ballistics experts, who once dominated the relatively small field of U.S. wildfire science, created "hypothetical universes in which fires burn only small, uniform, dead fuels on the forest floor." Yet Finney explained that fire does not spread according to averages: "It's actually the excursions, or the 
nonsteadiness, that allows fire to spread.” By averaging out nonsteady physics, these models built faulty intuitions, conjuring images of fire that themselves could prompt misjudgments in the field and suboptimal forms of response. ${ }^{14}$

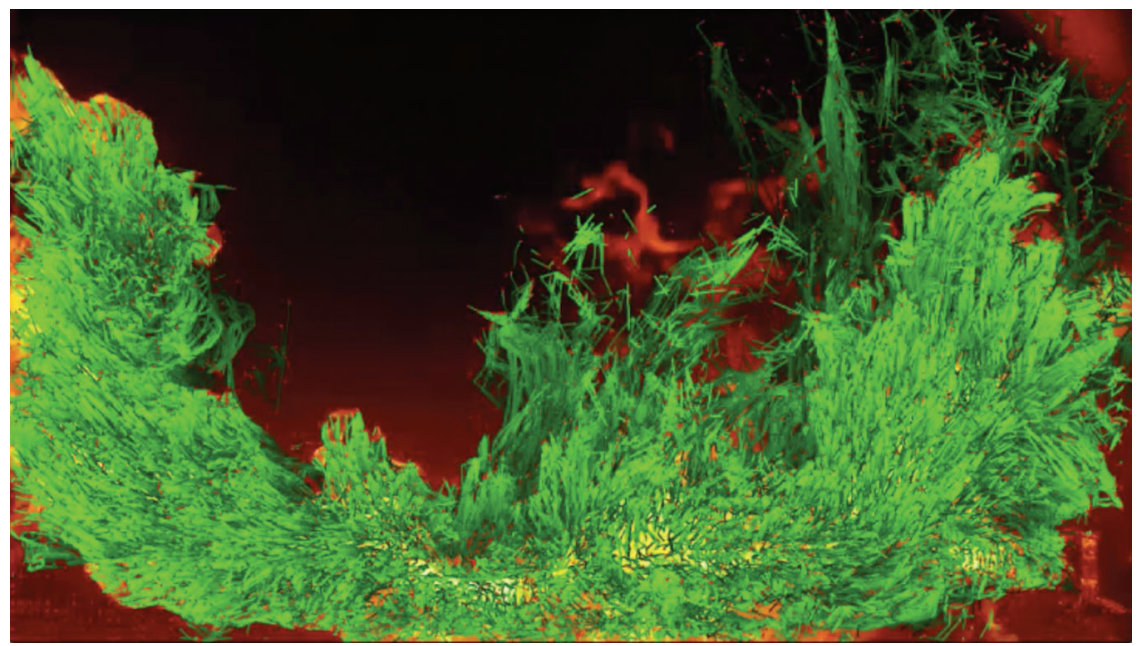

Figure 5. Still from video of a fire experiment, showing forward bursting and vertical patterns of flame peaks and troughs. Video from "Role of buoyant flame dynamics in wildfire spread," by Mark A. Finney et al., https://doi.org/10.1073/pnas.1504498112.

I am sitting with Finney in his office near the entryway of a two-story building on U.S. Highway 10. From here, a quiet hallway leads to a multistory burn chamber, where a palimpsest of experiments have tested or simulated fire ignition, buoyancy, and vorticity. There are used, abandoned, or ready-for-reuse apparatuses everywhere: wind tunnels and a combustion laboratory; one-of-akind air torches and a fire whirl simulator - all built over five decades and surrounded by heaps of ignition sources like cut cardboard and shredded wood. Highway 10 runs northwest from Missoula, past the airport, and merges onto an interstate that soon narrows into winding stretches of valley and high-mountain roads. We are right in the middle of the northern Rockies, where fires scorched more than a million acres between March and October of 2017, and where dominant models of fire behavior are losing the power of foresight.

"There is an expression that everyone says," Finney told me, "spreads like wildfire.' Yet we don't even know how wildfires spread.” Models of fire spread no longer align with the physical trajectories of fuels. Neither does the logic of suppression. The "hypothetical universes" of fire spread have left behind a vacuum and now, fire's physical worlds confront fire's hypothetical ones. The wildfire 


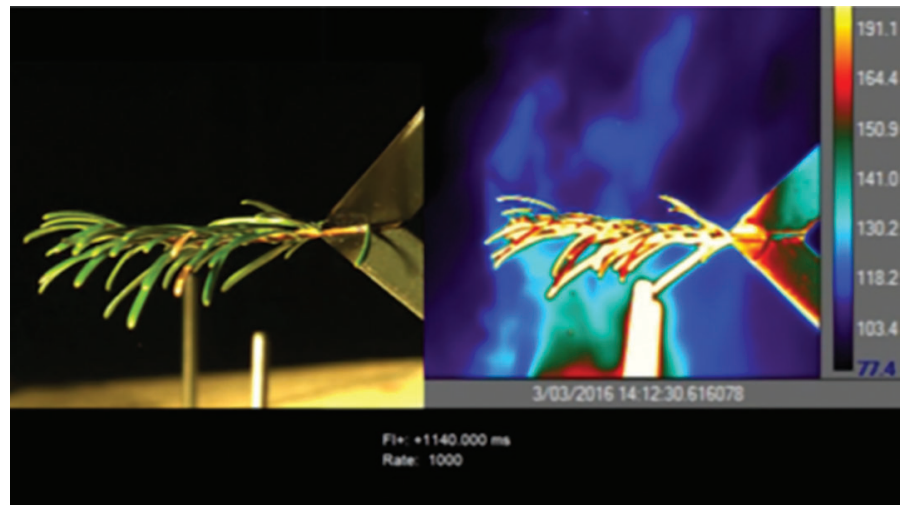

Figure 6. Two views of an ignition experiment showing the flammability of live fuel. Image from a 2017 presentation by Mark Finney at the Northern Rockies Training Center.

community refers to this sociotechnical aporia as the wildfire paradox, such that "the harder you try to suppress them, the worse they get when they happen." Well-intentioned suppression can create conditions for the next fire, creating new channels in the landscape for wildfires to travel. Couple these with Armstrong's harrowing scenes of the things wildfire is not supposed to do-spreading against the wind and even pushing its way up against it; burning into old fire scars and into places fire should not be able to burn - and one arrives at scenes of an almost nuclear devastation to which nothing can return. ${ }^{15}$

Finney asked me the same rhetorical question that Armstrong had: "You wouldn't throw people at hurricanes, right?" When I heard the comparison this time, I became attuned to a particular aspect of acceleration; the rate at which the phenomenon of wildfire was overtaking the techniques of its suppression was such that any human projection of its behavior was bound to fail, with dire consequences for emergency responders. This failure was not lost on Bachelard, who pointed to how scientific entities can outrun techniques of their objectification with his concept of the phenomenotechnique. ${ }^{16}$ In his classic text The Psychoanalysis of Fire, Bachelard $(1964,6)$ described fire as "a striking immediate object," but one that is "no longer a reality for science." The notion of the phenomenotechnique captures how this cognitive dissonance evacuates thought, such that, as Finney remarked, "we no longer know what fire is." Wildfire, as a strikingly immediate object, morphs into an array of disruptive unknowns.

In the meantime, complex critical thresholds have been crossed, although the details of such traversals - where and when they occur-are not precisely understood. In the gap between the expected and what actually occurs, the very 


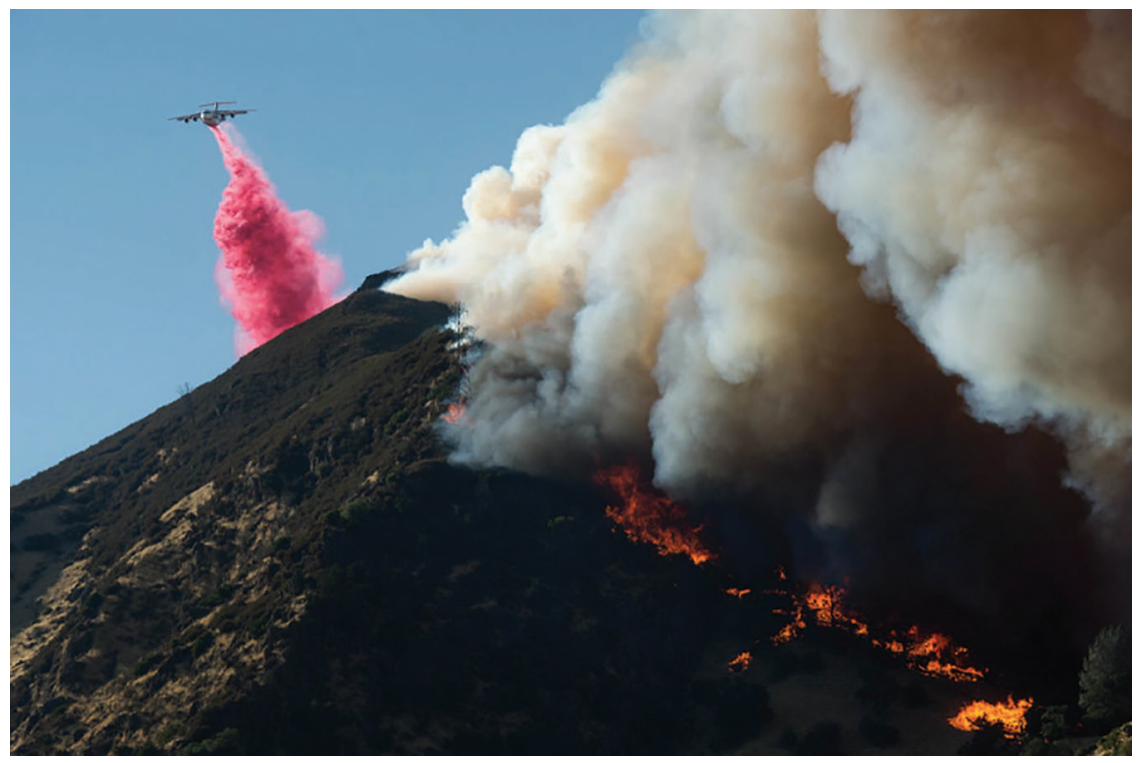

Figure 7. Air tanker dropping flame retardant on the 2016 Cold Fire. Photo courtesy of Noah Berger.

concept of projection is at stake - trainers tell firefighters to throw away their old mental slides; fire researchers tell their colleagues in the field that they have been looking at fire in the wrong ways; dispatchers tell forest supervisors that there is no one left to recruit to fight fires; engineers seek otherworldly materials to thermally enhance emergency fire shelters. They recently tested materials from NASA designed to thermally protect spacecraft upon atmospheric re-entry, but these materials did not hold up well against fire temperatures on Earth.

\section{BENEATH THE AIRSHOW}

Climate change has been described as a form of violence "that is neither spectacular nor instantaneous, but rather incremental and accretive, its calamitous repercussions playing out across a range of temporal scales" (Nixon 2011, 2). Since these lines were written, slow climate change has morphed into a multiplier of threat known as abrupt climate change (National Academy of Sciences 2013). Yet this shift in the spatiotemporal registers of threat (or, "the upper limits of bad") is not necessarily correlated with "existential crisis" or reflected "as a mode of political mobilization" (Masco 2017, S65). Rather, it can engender more of the same response and greater tolerance for paradoxes and cognitive dissonance. How so? If the wildfire paradox creates new extremes, it normalizes these through 
a cultural spectacle of suppression. Beneath what observers call the "airshow" (Erickson 2016) of flame retardant-throwing air tankers and every instrument of suppression available, I found researchers who saw the spectacle of technological promise as illusory, pointing to other spectacles of wholesale loss like massive forest die-offs due to heat and drought, as well as asking hard questions about ecosystem collapse and what mountain, forest, fire scar, or vegetation type might burn next. The airshow metaphor speaks to the way that suppression practices become dissonant with, and even provoke, landscape ignitability and flammability under future climate conditions (Abatzoglou and Williams 2016). Yet the exemplary form of rescue on the table, geoengineering - which promises to reverse the warming effects of greenhouse-gas emissions - furthers a state of dissonance in at least one sense: geoengineering can never reverse what has already happened to Earth's fuels. Where new research paths must be forged to get ahead of future climate conditions, technologies themselves can embed cognitive dissonance and varieties of "quitting thinking." As Jack Cohen told me, "I'm watching for a reality response, rather than a fatalistic one; an intellectual response, rather than a visceral one." The former are crucial today because when faced with an actively altering environment, Cohen noted, "we will need knowledge of how not to break things even further."

I began this essay with the claim that runaway change is a concept that points not only to changing ecologies but also to a set of broadening disconnects in which there is - in the most general sense - the loss of a foothold. Fire researchers saw the wildfire paradox as constricting operability, almost to the point of futility, and occasioning a search for new horizons. Along the way, senses of paradox were personally felt. As one observer shared with me: "We focus on safety. Go out there and be safe. And the counter to that is, 'That's bullshit. You can't.'” Today, such life-or-death dilemmas are informing how wildfire communities negotiate their continued engagement with (or retreat from) wildfire. In understanding these negotiations, we get a glimpse of what it means for an entire emergency sector to unsettle practices, protocols, and even intuitions and judgments that are no longer informative and possibly more jeopardizing. This dynamism is what horizoning is about: amid imperfect information, sustaining spaces for coordinated human action; stepping away from the primacy of prior models and, in doing so, revealing a host of underappreciated social and technical activities - the very material of ethnographic concept work that might, in turn, produce a different sort of projection. 
As I have suggested throughout this article, an inadequate foothold in changing realities can itself degrade knowledge about the future and the existential threats that are being brought forth. "So there's not a ton of horizon," Matt Jolly said to me. Researchers at the Fire Lab talk about using their insights into changes in fire behavior to avoid diligent insanity (that is, subservience to the tactics of fire suppression) and to work toward "acquiring horizon" - a potential tool for deciding what, in Jolly's words, "we actually are going to do over the next week, not like the next hour." Such a tool would pry time from the pace of runaway change and make futures less remote. In this new proximate time, what Cohen calls "visceral" responses (and the anxieties making them difficult to rein in) are tempered, strategy and safety protocols can be updated or rethought. Runaway change is thus more than an amalgam of onrushing disasters and hyperobjects. It is also the unsettling transformation of things we thought we knew-old fire scars, live vegetation, California mountains in December that are not supposed to burn - and a constant appeal for a "reality response." As new ecological trajectories materialize, they form new intersections relative to human and technical time. "Climate change is pretty much a done deal for the next several hundred years," Cohen told me, and yet this momentum-driven process poses the prospect of what he called a "massive ecological mistake." In "gearing up to continue fighting wildfire with more people and more equipment . . . you're going to see something go away. What I really mean is that we need to act in a way that we are not cutting off options for future generations."

Not cutting off options means regarding the future as recoverable while enacting ways to avert its abandonment today. In their efforts, my interlocutors are working to secure enough time to act while avoiding a norm of horizon deprivation. In a recent talk, the Russian-American journalist Masha Gessen (2017) described the situation in her home country, where life is reduced to an eternal present, in terms of "that state of low-level dread where we're always reacting to the latest outrage." Between the apocalyptic on the one hand and varieties of denialism on the other, horizons cut a different path. They are, after all, instruments - helping humans carve out effective perceptual range and guard against the threat of being blindsided. Seafarers, especially in a dense fog or storm, have a special ability to grasp the kinetics of real situations. They register increments of movement using sensory parameters - the smell of a certain forest, certain patterns in tidal waters - and deduce their position vis-à-vis previously estimated locations. This is not a technical fix, but rather a countertechnique: a continual capacity for recalibration, a horizoning that makes good on faulty or fleeting 
information, allowing forward momentum and preventing the crash (or disappearance) of an entire system (whether a lake, a forest, a boat, or a world).

Today, the Anthropocene stands as a new banner for the impact of human activity on the Earth's ecosystems (Crutzen 2002). Abrupt ecological change implies a deepening incompatibility between human and geological time scales, understood as a temporally dimensionless invisible present in which only dangerous surprises can emerge. This condition is one of attrition and loss: a situation of "absolute existential improvisation" for selves and a present literally "out of time" (Malabou 2012, 2). I have been foregrounding a different set of concerns pertaining to an all-too-real human struggle to maintain responsive capacity relative to an absent object. This struggle is not only about achieving better projections of risk or uncertainty. It is also about cultivating a cognizance of jeopardy faced by entire systems and about recovering the time in which such cognizance becomes actionable rather than obsolete. When destructiveness obliges us to revise knowledge calibrated to conditions that no longer exist, marking horizons beyond which the world as we know it disappears is itself an exercise in delimiting the knowable, and thus livable, world.

\begin{abstract}
Ecosystem changes are happening with surprising speed and on much shorter-thanprojected time scales. This essay explores the complexities of such abrupt environmental shifts, how scientists conceptualize a runaway nature, and how uncertainty poses a problem of projection and action. Its ethnographic material engages contexts where rapidly faltering projections and policies interface in unsettled ways with the realities of emergency response, especially to wildfires. Attuned to the political and existential hazards at work in a science of critical transitions, the essay argues for the importance of a distinct kind of intellectual and ethical labor, horizoning work, amid physical worlds on edge. [knowledge production; wildfire; climate change; critical transitions; horizoning work]
\end{abstract}

\title{
NOTES
}

Acknowledgments I thank my interlocutors for taking the time to share their work and vision with me. I am grateful to James Faubion, Dominic Boyer, Cymene Howe, and Marcel LaFlamme, as well as to four anonymous reviewers at Cultural Anthropology for their generous and sharp comments. A special thanks goes to Cameron Brinitzer and Michael Joiner for insightful conversation and feedback on this essay, as well as to Naomi Zucker, Paul Mitchell, Sara Rendell, João Biehl, and the audiences with whom I have shared this work. The School for Advanced Research, the National Science Foundation, and Princeton University's Center for Human Values have supported my research.

1. In their classic book Leviathan and the Air-Pump, Steven Shapin and Simon Schaffer (1985) show how vacuums were only as good as the vacuity their instrumentation generated. 
As this seventeenth-century conundrum shows, a vacuum is not just an empty space; it is a political and technical achievement in which truths depend on the integrity of their instruments as much as on processes of elimination.

2. An important early contribution to this literature pertained to planetary boundaries as "safe operating spaces" (Rockström et al. 2009) for humanity. For a conceptual genealogy of critical threshold science and instability, see Petryna and Mitchell 2017.

3. In using the term milieu, I draw from historian and philosopher of science Georges Canguilhem's (2001) seminal essay “The Living and Its Milieu." In it, Canguilhem demonstrates relations between organisms (the living, le vivant) and the milieu, arguing that each is never what it is without changing the other. Yet given a current situation of runaway change, I am somewhat suspicious of Canguilhem's vital optimism as the reimposition of the milieu becomes a pressing question.

4. For example, coastal scientists now believe that Hurricane Sandy, projected as a ninehundred-year storm, was, in fact, a five- to ten-year storm. On the disintegration of projections, see O'Reilly, Oreskes, and Oppenheimer 2012. For an analysis of Sandy and the projected return period in coastal flooding analyses, see N. Lin et al. 2016.

5. Drought and temperature rise help fuel fire, but a hundred-year history of fire suppression has accumulated unburned brush and other dead fuels that are now exploding.

6. With regard to this latter path, I am interested in how assumptions underpinning one type of projection fall apart and give way to new types of measures, truths, and responses.

7. For example, ground fires are transitioning faster to crown fires, in which wildfire rapidly spreads from treetop to treetop. Such fires occur in a range of inoperability (currently estimated as 2 percent of fires occurring in the United States) for which, according to Jolly, "no matter what you do, you're not actually going to effect change." As this range of escape increases, various managers are defining criteria for inoperability to clarify the conditions in which they can act.

8. Such fires actually move around based on the areas of highest fuel availability or areas of driest fuels, and do not, therefore, always conform to models of predictable spread. For a sharp analysis of how race and class difference is policed through a politics of nature in New Mexico, see Kosek 2006.

9. On the concept of malignant normality, see Lifton 2017.

10. The question of time and the future has been central to the anthropology of climate change. Jerome Whitington's $(2013,308)$ focus on specific material relations providing grammars of future climatic apprehension goes far in building a vocabulary "for imaginative and evaluative judgment about the subtle yet pervasive changes at work in planetary ecology." On uncertainty as a mode of anthropological apprehension and a departure from risk-centered scholarship, see Samimian-Darash and Rabinow 2015. Along other lines, scholars have reflected on "chronopolitical experiments" (Zee 2017, 218) around knowledge production, spatial and temporal strategies with respect to resistance and refusal (Ahmann 2017), the demands of "telling time" (Howe 2016), and climate change qua emergent forms of life (Callison 2014) as challenges to the Anthropocene's unitary planetary timeframe (see also Moore 2016). Michael Fischer's (2018) analytic of temporal framing as it remakes action within social systems is vital here, as is João Biehl and Peter Locke's (2017, ix) account of the “open-endedness of people's becoming" within these systems.

11. Such instructions are based on weather patterns, topography, vegetation, or other changes in fire behavior that may not be immediately apparent to crewmen in the field because of smoke or other visual obstructions. As one firefighter told me: "Maybe you can't see very far and you don't know what's going on and you don't know where the fire is. Maybe the fire's down below you. Maybe you're in a situation where you can't cover much territory if it starts spotting in on you."

12. A smokejumper is a wildland firefighter who jumps (with a parachute) into a forest fire for an initial attack. 
13. Petrilli's experience and that of his surviving colleagues is recounted in Maclean 1999. While most firefighters will never be in a position to use these shelters, postaccident reviewers have found that fallen firefighters sometimes had not recognized that they were in the process of being entrapped.

14. In a 2016 interview, Finney told me: "When we take that wrong intuition and we make observations out in the field, in wildland fire settings, we can easily misinterpret what's going on." On fundamental discoveries about the mechanisms of wildfire spread, see Finney et al. 2015.

15. Megafires recurring at more frequent intervals also invite further scenes of degradation, hindering postfire recovery and often leaving "only bare dirt and tree stumps" (HeyckWilliams, Anderson, and Stein 2017, 4).

16. Bachelard first used this concept to analyze the birth of a new science, microphysics (Castelão-Lawless 1995). On phenomenotechnique as "part thing, part theorem," see Rheinberger 2010, 27. On the phenomenotechnique designating phenomena that are "constituted by the material setting of the laboratory," see Latour and Woolgar 1986, 64. On environmental disaster and abrupt climate change as new phenomena that eclipse these material settings, see Petryna 2013 and 2015.

\section{REFERENCES}

Abatzoglou, John T., and A. Park Williams

2016 "Impact of Anthropogenic Climate Change on Wildfire across Western U.S. Forests." Proceedings of the National Academy of Sciences 113, no. 42: 11770-75.

Ahmann, Chloe

2017 “'It's exhausting to create an event out of nothing': Slow Violence and the Manipulation of Time." Cultural Anthropology 33, no. 1: 142-71. https:// doi.org/10.14506/ca33.1.06.

Bachelard, Gaston

1964 The Psychoanalysis of Fire. Translated by Alan C. M. Ross. New York: Beacon Press. Originally published in 1938.

Biehl, João, and Peter Locke

2017 "Foreword: Unfinished." In Unfinished: The Anthropology of Becoming, edited by João Biehl and Peter Locke, ix-xiii. Durham, N.C.: Duke University Press.

Callison, Candis

2014 Forms of Life: How Climate Change Comes to Matter. Durham, N.C.: Duke University Press.

Canguilhem, Georges

2001 “The Living and Its Milieu.” Translated by John Savage. Grey Room, no. 3: 631. Originally published in 1952. https://doi.org/10.1162/ 152638101300138521 .

Castelão-Lawless, Teresa

1995 "Phenomenotechnique in Historical Perspective: Its Origins and Implications for Philosophy of Science." Philosophy of Science 62, no. 1: 44-59. https://doi.org/ $10.1086 / 289838$.

Choy, Timothy, and Jerry Zee

2015 “Condition-Suspension.” Cultural Anthropology 30, no. 2: 210-23. https:// doi.org/10.14506/ca30.2.04.

Clark, Nigel

2012 "Rock, Life, Fire: Speculative Geophysics and the Anthropocene.” Oxford Literary

Crutzen, Paul J.

Review 34, no. 2: 259-76. https://doi.org/10.3366/olr.2012.0045.

2002 “Geology of Mankind.” Nature 415: 23. https://doi.org/10.1038/415023a.

Curwen, Thomas

2017 "California's Deadliest Wildfires Were Decades in the Making. 'We have forgotten what we need to do to prevent it." Los Angeles Times, October 22. 
http:/ /www.latimes.com/local/california/la-me-fire-perspectives-20171022story.html.

Dakos, Vasilis, et al.

2012 "Methods for Detecting Early Warnings of Critical Transitions in Time Series Illustrated using Simulated Ecological Data.” PLOS One 7: e41010. https://

De Landa, Manuel doi.org/10.1371/journal.pone.0041010.

2010 Deleuze: History and Science. New York: Atropos.

Downey, Clare

2017 "Why are California's Wildfires So Out of Control?" Video. Guardian, December 8.

https://www.theguardian.com/world/video/2017/dec/08/why-are-californiaswildfires-so-out-of-control-video-explainer.

Drijfhout, Sybren, Sebastian Bathiany, Claudie Beaulieu, Victor Brovkin, Martin Claussen,

Chris Huntingford, Marten Scheffer, Giovanni Sgubin, and Didier Swingedouw

2015 "Catalogue of Abrupt Shifts in Intergovernmental Panel on Climate Change Climate Models." Proceedings of the National Academy of Sciences 112, no. 43: E5777-86.

Erickson, David

2016 "Observation Fire 15 Percent Contained, New Fire Breaks Out Near Lincoln." Missoulian, July 4. https://missoulian.com/news/local/updated-observationfire-percent-contained-new-fire-breaks-out-near/article_33f4c6fd-afc6-5ff2bd51-a19b1aeb51b0.html.

Finney, Mark A., Jack D. Cohen, Jason M. Forthofer, Sara S. McAllister, Michael J.

Gollner, Daniel J. Gorham, Kozo Saito, Nelson K. Akafuah, Brittany A. Adam, and Justin

D. English

2015 “Role of Buoyant Flame Dynamics in Wildfire Spread.” Proceedings of the National Academy of Sciences 112, no. 32: 9833-58. https://doi.org/10.1073/pnas. 1504498112.

Fischer, Michael M. J.

2018 Anthropology in the Meantime: Experimental Ethnography, Theory, and Method for the Twenty-First Century. Durham, N.C.: Duke University Press.

Gessen, Masha

2017 "Trump and Russia: A Conversation with Scholars and Journalists." Panel discussion, Princeton University, Princeton, N.J., March 9.

Guterl, Fred

2012 The Fate of the Species: Why the Human Race May Cause Its Own Extinction and How We Can Stop It. New York: Bloomsbury.

Haraway, Donna J.

2016 Staying with the Trouble: Making Kin in the Chthulucene. Durham, N.C.: Duke University Press.

Heyck-Williams, Shannon, Lauren Anderson, and Bruce A. Stein

2017 “Megafires: The Growing Risk to America's Forests, Communities, and Wildlife." Washington, DC: National Wildlife Federation. https://www.nwf.org/ Holthaus, Eric

Educational-Resources/Reports/2017/10-19-2017-Megafires.

2017 "The First Wintertime Megafire in California History is Here." Grist, December 8. https://grist.org/article/the-first-wintertime-megafire-in-california-historyis-here.

Howe, Cymene

2016 “Timely." In "Lexicon for an Anthropocene Yet Unseen", Theorizing the Contemporary series edited by Cymene Howe and Anand Pandian, Cultural

Ingold, Tim Anthropology website, January 21. https://culanth.org/fieldsights/800-timely.

2011 Being Alive: Essays on Movement, Knowledge and Description. New York: Routledge. 
Jolly, W. Matt, Mark A. Cochrane, Patrick H. Freeborn, Zachary A. Holden, Timothy J.

Brown, Grant J. Williamson, and David M. J. S. Bowman

2015 “Climate-Induced Variations in Global Wildfire Danger from 1979 to 2013.” Nature Communications 6. https://doi.org/10.1038/ncomms8537.

Kosek, Jake

2006 Understories: The Political Life of Forests in Northern New Mexico. Durham, N.C.: Duke University Press.

Latour, Bruno, and Steve Woolgar

1986 Laboratory Life: The Construction of Scientific Facts. 2nd edition. Princeton, NJ: Princeton University Press. Originally published in 1979.

Lenton, Timothy M.

2011 "Early Warning of Climate Tipping Points." Nature Climate Change 1: 201-209. https://doi.org/10.1038/nclimate1143.

Lifton, Robert Jay

2017 The Climate Swerve: Reflections on Mind, Hope, and Survival. New York: New Press.

Lin, Brenda B., and Brian Petersen

2013 "Resilience, Regime Shifts, and Guided Transition under Climate Change: Examining the Practical Difficulties of Managing Continually Changing Systems." Ecology and Society 18, no. 1. https://doi.org/10.5751/ES-05128-180128.

Lin, Ning, Robert E. Kopp, Benjamin P. Horton, and Jeffrey P. Donnelly

2016 "Hurricane Sandy's Flood Frequency Increasing from Year 1800 to 2100." Proceedings of the National Academy of Sciences 113, no. 43: 12071-75. https://

Maclean, John N. doi.org/10.1073/pnas.1604386113.

1999 Fire on the Mountain: The True Story of the South Canyon Fire. New York: William Morrow.

Mahony, Martin, and Mike Hulme

2012 "The Color of Risk: An Exploration of the IPCC's 'Burning Embers' Diagram." Spontaneous Generations 6, no. 1: 75-89. https://doi.org/10.4245/sponge. v6i1.16075.

Malabou, Catherine

2012 The Ontology of the Accident: An Essay on Destructive Plasticity. Translated by Carolyn Shread. Malden, Mass.: Polity. Originally published in 2009.

Masco, Joseph

2017 “The Crisis in Crisis.” Current Anthropology 58, S15: S65-76. https://doi.org/ $10.1086 / 688695$.

Moore, Amelia

2016 "Anthropocene Anthropology: Reconceptualizing Contemporary Global Change." Journal of the Royal Anthropological Institute 22, no. 1: 27-46. https:// doi.org/10.1111/1467-9655.12332.

Morton, Timothy

2013 Hyperobjects: Philosophy and Ecology after the End of the World. Minneapolis: University of Minnesota Press.

National Academy of Sciences

2013 Abrupt Impacts of Climate Change: Anticipating Surprises. Washington, DC: National Academies Press. https://www.nap.edu/catalog/18373/abrupt-impacts-ofclimate-change-anticipating-surprises.

National Interagency Fire Center

2014 "Wildland Safety Training Annual Refresher: 1994 South Canyon Fire on Storm King Mountain." Video. https://www.youtube.com/watch?v=0FZ98XJDzj0\& $\mathrm{t}=1591 \mathrm{~s}$. 
National Public Radio (NPR)

2016 "Columbia Journalism Report Criticizes Exxon CEO's Position on Climate Change.” All Things Considered, December 13. http://www.npr.org/2016/12/ 13/505442921/columbia-journalism-report-criticizes-exxon-ceos-position-onclimate-change.

Nixon, Rob

2011 Slow Violence and the Environmentalism of the Poor. Cambridge, Mass.: Harvard University Press.

Nordenson, Guy

2016 "Probabilistic Coastal Hazards Mapping for the United States." Princeton Environmental Institute faculty seminar, Princeton, N.J., September 20.

Norgaard, Kari Marie

2011 Living in Denial: Climate Change, Emotions, and Everyday Life. Cambridge, Mass.: MIT Press.

O’Reilly, Jessica, Naomi Oreskes, and Michael Oppenheimer

2012 "The Rapid Disintegration of Projections: Climate Science, Bureaucratic Institutions, and the West Antarctic Ice Sheet." Social Studies of Science 42, no.

Petryna, Adriana 5: 709-731. https://doi.org/10.1177/0306312712448130.

2013 Life Exposed: Biological Citizens after Chernobyl. Revised edition. Princeton, N.J.: Princeton University Press.

2015 "What is a Horizon? Navigating Thresholds in Climate Change Uncertainty." In Modes of Uncertainty: Anthropological Cases, edited by Limor Samimian-Darash and Paul Rabinow, 147-64. Chicago: University of Chicago Press.

Petryna, Adriana, and Paul Wolff Mitchell

2017 "On the Nature of Catastrophic Forms." BioSocieties 12, no. 3: 343-66. https:// doi.org/10.1057/s41292-017-0038-3.

Randalls, Samuel

2015 "Joshua P. Howe. Behind the Curve: Science and the Politics of Global Warming." Book review. Isis 106, no. 2: 503-505. https://doi.org/10.1086/682823.

Rheinberger, Hans-Jörg

2010 An Epistemology of the Concrete: Twentieth-Century Histories of Life. Durham, N.C.: Duke University Press.

Rockström, Johan, et al.

2009 “A Safe Operating Space for Humanity." Nature 461: 472-475. https: / / doi.org/ 10.1038/461472a.

Rojas, David

2016 "Climate Politics in the Anthropocene and Environmentalism beyond Nature and Culture in Brazilian Amazonia.” Political and Legal Anthropology Review 39, no. 1: 16-32. https://doi.org/10.1111/plar.12128.

Samimian-Darash, Limor and Paul Rabinow, eds.

2015 Modes of Uncertainty: Anthropological Cases. Chicago: University of Chicago Press. Scheffer, Marten, et al.

2012 “Anticipating Critical Transitions." Science 338: 344 48. https://doi.org/ $10.1126 /$ science. 1225244.

Shapin, Steven, and Simon Schaffer

1985 Leviathan and the Air-Pump: Hobbes, Boyle, and the Experimental Life. Princeton,

Short, Karen C. N.J.: Princeton University Press.

2017 "Rethinking Performance Measurement in U.S. Federal Wildland Fire Management." Presentation slide deck, Fire Behavior Workshop, Northern Rockies Training Center, Missoula, Mont., February 22-24. 
Solomon, Susan, Gian-Kasper Plattner, Reto Knuti, and Pierre Friedlingstein

2009 "Irreversible Climate Change due to Carbon Dioxide Emissions." Proceedings of the National Academy of Sciences 106, no. 6: 1704-1709. https://doi.org/ 10.1073/pnas.0812721106.

Walker, Ryan B., Jonathan D. Coop, Sean A. Parks, and Laura Trader

2018 "Fire Regimes Approaching Historic Norms Reduce Wildfire-Facilitated Conversion from Forest to Nonforest." Ecosphere 9, no. 4. https://doi.org/ $10.1002 /$ ecs2.2182.

White, James

2014 Public briefing on National Academy of Sciences report, "Abrupt Impacts of Climate Change: Anticipating Surprises.” Washington, DC, January 10. https:// www. youtube. $\mathrm{com} /$ watch? $\mathrm{v}=$ uh3auNaQbhc.

Whitington, Jerome

2013 "Fingerprint, Bellwether, Model Event: Climate Change as Speculative Zee, Jerry C. Anthropology." Anthropological Theory 13, no. 4: 308-328.

2017 "Holding Patterns: Sand and Political Time at China's Desert Shores." Cultural Anthropology 32, no. 2: 215-41. https://doi.org/10.14506/ca32.2.06. 